CASE REPORT

\title{
A novel mutation of the primary protein kinase $C$ phosphorylation site in the calcium-sensing receptor causes autosomal dominant hypocalcemia
}

\author{
Syndia Lazarus ${ }^{1,2}$, Carel J Pretorius ${ }^{3}$, Frederick Khafagi ${ }^{1}$, Katherine L Campion ${ }^{4}$, Sarah C Brennan ${ }^{5}$, \\ Arthur D Conigrave ${ }^{5}$, Edward M Brown ${ }^{6}$ and Donald T Ward ${ }^{4}$ \\ ${ }^{1}$ Department of Endocrinology, Royal Brisbane and Women's Hospital, Herston, Queensland 4029, Australia, ${ }^{2}$ Department of Endocrinology, Mater Adult \\ Hospital, South Brisbane, Queensland 4101, Australia, ${ }^{3}$ Department of Chemical Pathology, Pathology Queensland, Level 4, Block 7, Royal Brisbane and \\ Women's Hospital, Herston, Queensland 4029, Australia, ${ }^{4}$ Faculty of Life Sciences, University of Manchester, Manchester M13 9PL, UK, ${ }^{5}$ School of \\ Molecular Bioscience, University of Sydney, Sydney, New South Wales 2006, Australia and ${ }^{6}$ Division of Endocrinology, Diabetes and Hypertension and \\ Department of Medicine, Brigham and Women's Hospital, Boston, Massachusetts 02115, USA
}

(Correspondence should be addressed to C J Pretorius; Email: carel_pretorius@health.qld.gov.au)

\begin{abstract}
Objective: The calcium-sensing receptor (CASR) is a key controller of calcium homeostasis by regulating parathyroid hormone (PTH) secretion and renal calcium reabsorption. $\mathrm{CASR}^{\mathrm{T} 888}$ is a protein kinase $\mathrm{C}$ (PKC) phosphorylation site in the receptor's intracellular domain that has previously been identified as a critical negative regulator of CASR downstream signaling in vitro, but whose importance in vivo is unknown.

Case report: The proband presented with mild symptomatic hypocalcemia following treatment for nephrotic syndrome due to minimal change glomerulonephropathy. Laboratory tests revealed inappropriately normal PTH concentrations and relative hypercalciuria typical of autosomal dominant hypocalcemia. His asymptomatic father had similar laboratory test results.

Design and methods: The CASR gene was sequenced. To investigate the molecular consequences of $C A S R^{\mathrm{T} 888 \mathrm{M}}$ mutation, site-directed mutagenesis was used to modify the wild-type (wt)-CASR gene, with the resulting mutant being transfected transiently into HEK-293 cells.

Results: A novel CASR missense mutation, T888M, was identified in both cases. The $\mathrm{CASR}^{\mathrm{T} 888 \mathrm{M}}$ mutant exhibited enhanced sensitivity to extracellular calcium concentration, both for intracellular calcium $\left(\mathrm{Ca}_{\mathrm{i}}^{2+}\right)$ mobilization and for ERK phosphorylation, despite having unaltered levels of cell surface expression. Furthermore, CASR ${ }^{\mathrm{T} 88 \mathrm{M}}$ elicited sustained $\mathrm{Ca}_{\mathrm{i}}^{2+}$ mobilization rather than high frequency $\mathrm{Ca}_{\mathrm{i}}^{2+}$ oscillations, and, unlike the wt-CASR, the response was resistant to acute inhibition by the PKC activator, phorbol 12-myristate 13-acetate.

Conclusions: The clinical and functional data provide the first genotype-phenotype correlation for a mutation at T888, indicating its critical physiological importance in CASR signaling. Thus, CASR ${ }^{\mathrm{T} 888}$ represents a functionally important, inhibitory phosphorylation site that contributes to the control of PTH secretion.
\end{abstract}

European Journal of Endocrinology 164 429-435

\section{Introduction}

The calcium-sensing receptor (CASR; MIM + 601199) is a $\mathrm{G}$ protein-coupled receptor that is a key controller of extracellular calcium $\left(\mathrm{Ca}_{0}^{2+}\right)$ homeostasis. CASR is highly expressed in the chief cells of the parathyroid gland, but is also expressed in other tissues including the thyroid, kidney, gastrointestinal tract, and bone. Both loss-of-function and gain-of-function CASR mutations have been described (1-3).

Heterozygous loss-of-function mutations generally result in familial hypocalciuric hypercalcemia, and homozygous mutations result in neonatal severe hyperparathyroidism. The former is characterized by mild and the latter by severe hypercalcemia, together with inappropriately normal or frankly elevated parathyroid hormone (PTH) concentrations (1-3). Conversely, gain-of-function mutations resulting in impairment of PTH secretion and renal calcium and magnesium reabsorption manifest as autosomal dominant hypocalcemia (ADH) (1-3). More than fifty activating mutations have been described to date. These are collated at www. casrdb.mcgill.ca, and have been the subject of recent reviews $(4,5)$. Although often familial, de novo mutations are not uncommon, with one case study of 19 unrelated cases of isolated hypoparathyroidism identifying eight individuals with distinct CASR mutations (6). 
The phenotype of ADH is characterized by persistent hypocalcemia with clinical features that vary from asymptomatic through to asthenia, muscle cramps, paresthesia, carpopedal spasm, and even seizures, in combination with inappropriately low concentrations of PTH and relative hypercalciuria $(2,6)$. While in the hypocalcemic range, the serum total corrected calcium is almost never $<1.20 \mathrm{mmol} / \mathrm{l}$, with other suggestive features being a PTH within the normal range (i.e. around $1.0-6.0 \mathrm{pmol} / \mathrm{l}$ ), serum magnesium $\leq 0.70 \mathrm{mmol} / \mathrm{l}$ and a urine calcium:creatinine ratio $>0.30 \mathrm{mmol} / \mathrm{mmol}$ (2). Owing to the relative hypercalciuria, ADH is associated with an increased risk of nephrocalcinosis and renal impairment, particularly with the use of active vitamin $\mathrm{D}$ analogs (2, 6, 7). 1,25-dihydroxyvitamin D $\left(1,25(\mathrm{OH})_{2} \mathrm{D}\right)$ has been shown to up-regulate renal CASR expression, and increased expression of activated CASR may result in worsening hypercalciuria $(8,9)$.

While most mutations responsible for $\mathrm{ADH}$ are located in the extracellular regions of the CASR, several are located in the intracellular domain where they may influence trafficking, surface expression, and receptor signaling rather than agonist binding. An intracellular CASR residue known to be critical for the control of CASR activity in vitro is the protein kinase $\mathrm{C}(\mathrm{PKC})$ phosphorylation site threonine-888 (10-15); however, the in vivo effects of mutations at this site have not been described previously. In this study, we describe a family with ADH due to a novel T888M missense mutation and thus demonstrate the importance of this residue to CASR signaling in vivo.

\section{Case report}

The proband was a 24-year-old Caucasian male who was referred for evaluation of hypocalcemia. Eight months previously, he had developed nephrotic syndrome due to biopsy-confirmed minimal change glomerulonephropathy that readily responded to prednisolone therapy. He had also been treated with calcium carbonate $1500 \mathrm{mg}$ and cholecalciferol $1000 \mathrm{IU} /$ day for osteoporosis prophylaxis. The treating nephrologist noted hypocalcemia after the proteinuria and hypoalbuminemia had resolved.

There was a history of intermittent muscle cramps and carpal spasms since childhood that had improved on one occasion following a short course of calcium and magnesium supplements. These symptoms recurred during his illness, but settled after calcium and cholecalciferol were started.

There was no history of neck trauma or surgery, hearing impairment, seizures, or febrile convulsions. There was no known family history of hypocalcemia. Examination was unremarkable apart from the presence of several psoriatic plaques consistent with a history of psoriasis from childhood.
Blood tests taken 2 years prior to his presentation with nephrotic syndrome showed that the total serum calcium corrected for albumin was low at $1.96 \mathrm{mmol} / \mathrm{l}$ (reference range 2.15-2.55), albumin was normal at $46 \mathrm{~g} / \mathrm{l}$ (reference range 35-50), and phosphate was high at $1.80 \mathrm{mmol} / \mathrm{l}$ (reference range 0.81-1.45). No action had been taken at that time. Blood tests performed during the hypoalbuminemic period associated with the nephrotic syndrome (serum albumin $<20 \mathrm{~g} / \mathrm{l})$ demonstrated apparently normal corrected calcium concentrations. However, the total corrected calcium concentration was clearly below the lower limit of normal (values between 1.97 and $2.18 \mathrm{mmol} / \mathrm{l}$ ) once the serum albumin normalized.

Investigations performed following referral showed that serum-ionized calcium was low at $1.05 \mathrm{mmol} / \mathrm{l}$ (reference range 1.15-1.35), serum magnesium was normal at $0.9 \mathrm{mmol} / \mathrm{l}$ (reference range $0.7-1.1$ ), intact PTH was inappropriately normal $(4.7 \mathrm{pmol} / \mathrm{l}$; reference range 1.0-7.0), 25-hydroxyvitamin $\mathrm{D}$ (250HD) was normal (132 nmol/l; reference range 50-150), but $1,25(\mathrm{OH})_{2} \mathrm{D}$ was elevated $(213 \mathrm{pmol} / \mathrm{l}$; reference range 40-153). Similar results were obtained on a repeat blood test 6 days later. The elevated $1,25(\mathrm{OH})_{2} \mathrm{D}$ concentration was further investigated with chest X-ray and serum angiotensin-converting enzyme concentration, which were normal, and QuantiFERON-TB Gold Assay for Mycobacterium tuberculosis, which was elevated. Subsequent serial morning sputum samples were negative for M. tuberculosis, and a tuberculin skin test was negative. Infectious disease review concluded that the patient had a minimal likelihood of M. tuberculosis infection, and a cause for the high $1,25(\mathrm{OH})_{2} \mathrm{D}$ level was not identified.

A random urinary calcium:creatinine ratio was $0.48 \mathrm{mmol} / \mathrm{mmol}$ (reference range $<0.4$ in normocalcemic individuals) with a paired corrected serum calcium of $2.18 \mathrm{mmol} / \mathrm{l}$. On a subsequent 24-h urinary specimen, the calcium:creatinine ratio was $0.15 \mathrm{mmol} /$ $\mathrm{mmol}$ with a paired serum calcium of $2.00 \mathrm{mmol} / \mathrm{l}$. Both samples were taken while the patient was taking calcium supplements.

Screening of relatives (father, mother, brother, and father's siblings), all of whom were asymptomatic, showed that the patient's father was also hypocalcemic, but not other family members. The father's serum total corrected calcium was $2.01 \mathrm{mmol} / \mathrm{l}$ and serum-ionized calcium was $1.06 \mathrm{mmol} / \mathrm{l}$, with an inappropriately normal serum PTH of $1.5 \mathrm{pmol} / \mathrm{l}$ and high urinary calcium:creatinine ratio of $0.43 \mathrm{mmol} / \mathrm{mmol}$. Serum phosphate $(1.3 \mathrm{mmol} / \mathrm{l})$, magnesium $(0.9 \mathrm{mmol} / \mathrm{l})$, and $250 \mathrm{HD}(103 \mathrm{nmol} / \mathrm{l})$ were normal. Unlike the index case, $1,25(\mathrm{OH})_{2} \mathrm{D}$ was normal $(111 \mathrm{pmol} / \mathrm{l})$. These findings led us to suspect the presence of a heterozygous gain-of-function mutation of the CASR in the proband and his father consistent with a diagnosis of $\mathrm{ADH}$. Informed consent for further testing and publication of the findings was obtained. 


\section{Methods}

\section{Biochemical tests}

Routine laboratory analytes were assayed on a Beckman Coulter UniCel DxI 800 analyzer (Beckman Coulter Diagnostics, Brea, CA, USA). Calcitonin and PTH were measured on a Siemens Immulite 2000 analyzer (Siemens Medical Solutions Diagnostics Ltd, Malvern, PA, USA). Serum 250HD was measured with ultraperformance liquid chromatography followed by tandem mass spectrometry (16), and serum $1,25(\mathrm{OH})_{2} \mathrm{D}$ was measured with an immunoassay (Diasorin, North Ryde, NSW, Australia).

\section{PCR product amplification and sequencing}

DNA sequencing of the CASR gene was performed on extracted genomic DNA with an automated sequencer (ABI Prism; Perkin-Elmer Corp., Wellesley, MA, USA) as previously described (17).

\section{Site-directed mutagenesis and cell culture}

The T888M mutation was introduced by site-directed mutagenesis using the QuikChange (Stratagene, Agilent Technologies, Stockport, Cheshire, UK) method with the wild-type (wt) human parathyroid CASR in pcDNA3.1 as the template. HEK-293 cells were transiently transfected (FuGENE-6, Roche Diagnostics) with wt-CASR or CASR ${ }^{\mathrm{T} 888 \mathrm{M}}$ and grown on glass coverslips in DMEM containing $10 \%(\mathrm{v} / \mathrm{v})$ heat-inactivated fetal bovine serum (Invitrogen Ltd).

\section{Total cellular CASR protein expression}

Protein expression was demonstrated by western blotting as described previously, using an anti-CASR mouse MAB (amino acids 214-235 of human CASR; Affinity Bioreagents, Golden, CO, USA) $(18,19)$. Briefly, cells were lysed in detergent-containing buffer supplemented with protease inhibitors and $N$-ethylmaleimide $(1 \mathrm{mM})$, the lysate was centrifuged at $10000 \boldsymbol{g}$ $\left(10 \mathrm{~min}, 4^{\circ} \mathrm{C}\right)$, and the supernatant was solubilized in Laemmli buffer at $65^{\circ} \mathrm{C}(3 \mathrm{~min})$.

\section{Intracellular calcium assay}

CASR-induced changes in intracellular calcium $\left(\mathrm{Ca}_{\mathrm{i}}^{2+}\right)$ concentration were measured by epifluorescence microscopy as described previously $(11,12)$ using cells loaded with Fura-2 (Invitrogen). CASR-transfected cells were then incubated at room temperature in Experimental Buffer (20 mM HEPES (pH 7.4), $125 \mathrm{mM}$ $\mathrm{NaCl}, 4 \mathrm{mM} \mathrm{KCl}, 0.5 \mathrm{mM} \mathrm{CaCl} 2,0.5 \mathrm{mM} \mathrm{MgCl}_{2}$, and $5.5 \mathrm{mM}$ glucose) and exposed to increasing concentrations of $\mathrm{Ca}_{0}^{2+}$ to establish the relative $\mathrm{Ca}_{0}^{2+}$ sensitivities of the receptors.

\section{Cell surface expression}

HEK-293 cells were transfected transiently with FLAGtagged (extracellular) CASR constructs. After $48 \mathrm{~h}$, the cells were incubated with mouse monoclonal DDDDK tag antibody (G10; $1 \mu \mathrm{g} / \mathrm{ml}$; Abcam, Sapphire Bioscience, Waterloo, Australia) in DMEM (10\% fetal bovine serum (FBS)) for $2 \mathrm{~h}\left(4{ }^{\circ} \mathrm{C}\right.$ with gentle rocking), and then washed and collected with ice-cold PBS and pelleted by centrifugation. Cells were then incubated with HRP-conjugated goat anti-mouse IgG antibody (1:5000; Sigma-Aldrich) in DMEM (10\% FBS) for $1 \mathrm{~h}$ $\left(4{ }^{\circ} \mathrm{C}\right.$ with vigorous shaking). Cells were pelleted and washed as before and then incubated with $3,3^{\prime}, 5,5^{\prime}$ tetramethylbenzidine (Sigma-Aldrich) for $20 \mathrm{~min}$ (in the dark with rocking), and the reaction was then stopped with an equal volume of $1.0 \mathrm{M} \mathrm{HCl}$. Cells were pelleted, and then the absorbances of the supernatants were read in triplicate at $450 \mathrm{~nm}$. Absorbances were corrected for background using an untransfected control and expressed as percentages of the cell surface expression of a wt control.

\section{ERK phosphorylation}

HEK-293 cells transfected transiently with CASR were assayed for ERK phosphorylation as previously described (19). Briefly, cells were exposed to buffer containing various $\mathrm{Ca}_{\mathrm{o}}^{2+}$ concentrations at $37^{\circ} \mathrm{C}$ for $10 \mathrm{~min}$ (or to $4 \mathrm{mM} \mathrm{Ca}_{\mathrm{o}}^{2+}$ for various time points up to $20 \mathrm{~min}$ ) prior to lysis on ice in RIPA buffer supplemented with protease and phosphatase inhibitors. ERK phosphorylation was then determined by semi-quantitative immunoblotting using a phospho-specific antibody (Pierce, Fisher Scientific UK Ltd, Loughborough, UK).

\section{Presentation of data and statistical analysis}

The data are presented as means \pm s.E.M., and statistical significance between datasets was determined by Student's unpaired or paired t-test (GraphPad Prism, La Jolla, CA, USA).

\section{Results}

Sequence analysis of exon 7 of the CASR genomic DNA in both the proband and his father revealed a heterozygous substitution of cytosine with thymidine at position 2663 (CASR:c.[2663C > T]) (Fig. 1). This mutation was predicted by PolyPhen (prediction of functional effect of human nsSNPs; http://genetics. bwh.harvard.edu/pph/) to have a position-specific independent counts (PSIC) score of 1.711, and 
A Wild-type

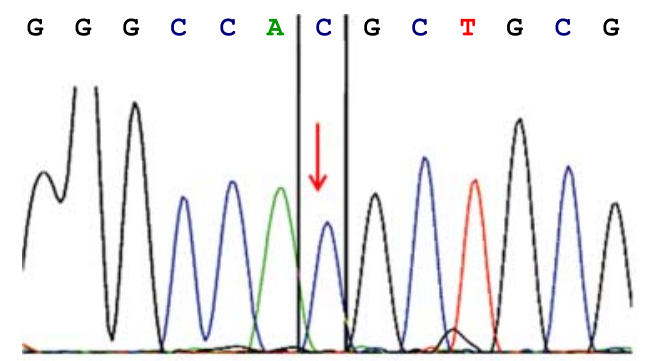

B c. $2663 C>T$

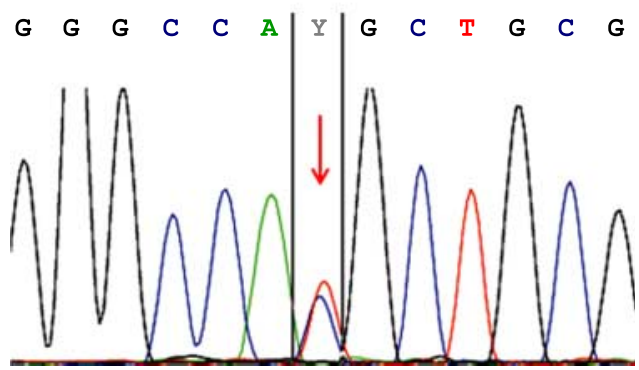

Figure 1 Representative sequence analysis of exon 7 of the $C A S R$ in the proband and his father (B). The wild-type sequence (NM_000388.2) is included for comparative purposes (A). The heterozygous substitution of cytosine with thymidine at position 2663 (CASR:c.[2663C > T]) is predicted in silico to result in the substitution of a methionine for threonine at position 888 (p.Thr888Met) and thus abolish the phosphorylation site. Full colour version of this figure available via http://dx.doi.org/10.1530/EJE-10-0907.

modeling of the effect on the amino acid sequence of the CASR protein predicted a substitution of methionine for threonine at position 888 (p.T888M) that would abolish a major intracellular PKC phosphorylation site (12).

\section{Functional characterization of the $\mathrm{CASR}^{\text {T888M }}$ mutation in HEK-293 cells}

To investigate the functional consequence of the $C A S R^{\mathrm{T} 888 \mathrm{M}}$ mutation in vitro, the mutation was recapitulated by mutating the wt-CASR cDNA. $\mathrm{CASR}^{\mathrm{T} 888 \mathrm{M}}$ exhibited an apparent increase in $\mathrm{Ca}_{0}^{2+}$ sensitivity relative to wt-CASR, and the $\mathrm{EC}_{50}$ for $\mathrm{Ca}_{0}^{2+}$ decreased significantly (Fig. 2; wt, $3.0 \pm 0.1 \mathrm{mM}$; T888M, $2.5 \pm 0.2 \mathrm{mM} ; P<0.05$ by unpaired $t$-test of $\log \mathrm{EC}_{50}$ values). Western blotting revealed similar expression of protein bands consistent with the wellrecognized $140 \mathrm{kDa}$ core-glycosylated and $160 \mathrm{kDa}$ mature receptors $(7,12-15,20)$ in both sets of transfected cells (Fig. 2C). In addition, there was no difference in cell surface expression between wt-CASR $(100 \pm 6.4 \%)$ and CASR $^{\text {T888M }}(93.9 \pm 4.9 \%)$ FLAGtagged constructs in their respective extracellular domains.

Next, to investigate the consequence of the T888M mutation on the recognized inhibitory effect of phorbol ester treatment, wt-CASR- and $C A S R^{\mathrm{T} 888 \mathrm{M}}$-transfected cells were exposed to raised $\mathrm{Ca}_{0}^{2+}$ concentration $(4 \mathrm{mM})$ in the absence and then in the presence of $1 \mu \mathrm{M}$ phorbol 12-myristate 13-acetate (PMA), a PKC stimulator. For wt-CASR, high $\mathrm{Ca}_{o}^{2+}$ concentration induced rapid $\mathrm{Ca}_{\mathrm{i}}^{2+}$ oscillations that were abolished within 2 min of PMA cotreatment (Fig. 3A; in the absence of PMA, $\mathrm{Ca}_{\mathrm{i}}^{2+}$ oscillations continued for at least $10 \mathrm{~min}$ (12)). In contrast, $\mathrm{CASR}^{\mathrm{T} 888 \mathrm{M}}$ elicited mostly sustained $\mathrm{Ca}_{\mathrm{i}}{ }^{2+}$ mobilization that exhibited a time-dependent decay and resistance to PMA-induced inhibition (Fig. 3B).

Finally, the apparent increase in $\mathrm{Ca}_{0}^{2+}$ sensitivity seen with $\mathrm{CASR}^{\mathrm{T} 888 \mathrm{M}}$ with respect to $\mathrm{Ca}_{\mathrm{i}}^{2+}$ mobilization (Fig. 2) was also observed in experiments examining the effect of CASR activation on ERK phosphorylation (Fig. 4; WT, $3.4 \pm 0.2 \mathrm{mM}$; T888M, $2.6 \pm 0.2 \mathrm{mM}$; $P<0.01$ by paired $t$-test of $\log \mathrm{EC}_{50}$ values). The effects of $4 \mathrm{mM} \mathrm{Ca}_{0}^{2+}$ on each receptor as a function of time were broadly similar (up to $20 \mathrm{~min}$ ) though with a small but significant increase in ERK phosphorylation observed after $1 \mathrm{~min}$ for $\mathrm{CASR}^{\mathrm{T} 888 \mathrm{M}}$ receptor (Fig. 4C). No further differences were observed in the response time courses.
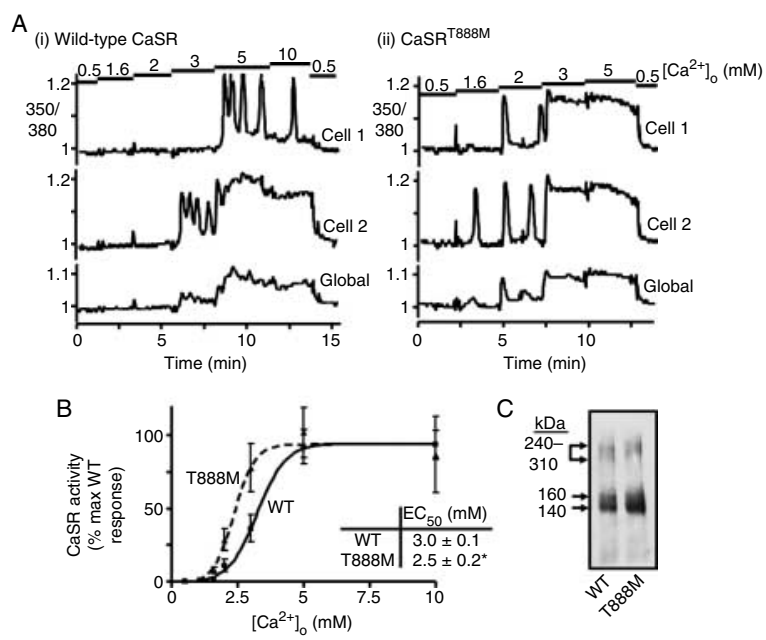

Figure 2 Extracellular $\mathrm{Ca}^{2+}$-induced $\mathrm{Ca}_{i}^{2+}$ mobilization in $\mathrm{HEK}-293$ cells transfected with either wild-type CASR or $C A S R^{\top 888 \mathrm{M}}$

(A) Fura2-loaded HEK-293 cells ((i) wild-type CASR; (ii) CASR $^{\text {T888M }}$ ) were treated with increasing $\mathrm{Ca}_{0}^{2+}$ concentrations $(0.5-10 \mathrm{mM})$, and the resulting changes in $\mathrm{Ca}_{i}^{2+}$ concentration (350/380 ratio) were measured by single cell microfluorometry. Representative traces show $\mathrm{Ca}_{\mathrm{i}}^{2+}$ changes in two single cells and a 'global' cluster of all of the responsive cells in the field of view. Results are representative of a minimum of nine coverslips from two independent transfections. (B) Concentration-effect curve for $\mathrm{Ca}_{o}^{2+}$-induced $\mathrm{Ca}_{i}^{2+}$ mobilization in wt-CASR- and $C A S R^{\top 888 M_{-}}$-transfected cells. Responses were defined as the area under the $350 / 380$ trace for the 'global' cluster, for the first 2 min following a change in $\mathrm{Ca}_{\circ}^{2+}$ concentration. CASR $^{\text {T888M }}$ exhibited a leftward-shifted concentration-effect curve relative to wt-CASR, with a significantly reduced $E C_{50}$ value (unpaired $t$-test; see inset; " $P<0.05$ ). (C) Anti-CASR immunoreactivity for wt-CASR and CASR ${ }^{\text {T88 }}$ showing $140 \mathrm{kDa}$ core glycosylated protein, $160 \mathrm{kDa}$ mature receptor, and a $240-310 \mathrm{kDa}$ band representing CASR dimers (18). 


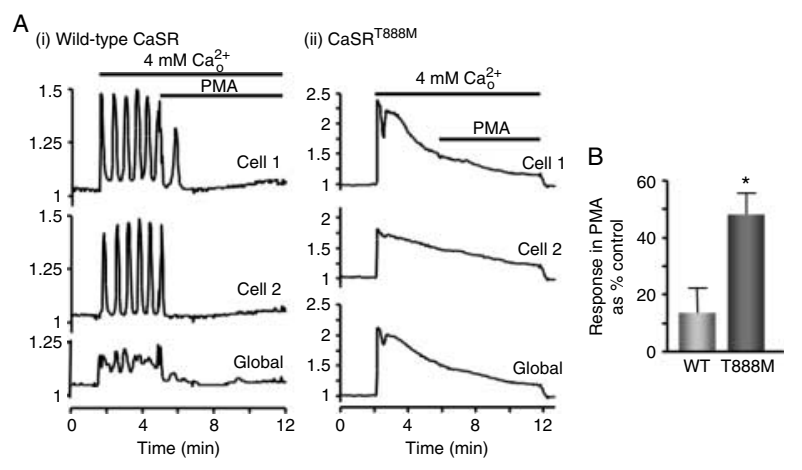

Figure 3 Effect of $C A S R^{\top 888 \mathrm{M}}$ mutation on phorbol ester-induced signal inhibition. (A) High $\mathrm{Ca}_{o}^{2+}$ concentration $(4 \mathrm{mM})$ was used to elicit CASR-mediated $\mathrm{Ca}_{\mathrm{i}}^{2+}$ mobilization resulting in oscillatory signaling for the wt-CASR and sustained $\mathrm{Ca}_{i}^{2+}$ signaling for CASR ${ }^{\text {T88MM }}$. Cotreatment with PMA $(1 \mu \mathrm{M})$ abolished the responses of wt-CASR but had an impaired effect on $\mathrm{CASR}^{\text {T888M }}$. Following removal of PMA and a brief recovery phase, cells regained or retained the responsiveness to high $\mathrm{Ca}_{0}^{2+}$ concentration (not shown). Median responses are shown and are representative of three separate coverslips. (B) The $\mathrm{Ca}_{i}^{2+}$ response to $4 \mathrm{mM} \mathrm{Ca}_{\circ}^{2+}$ (average area under the 350/380 'global' cluster trace per minute) during exposure to PMA expressed as a percentage of the average response per minute over the $3 \mathrm{~min}$ prior to exposure. CASR ${ }^{\top 888 \mathrm{M}}$ was largely unresponsive to PMA, whereas for wt-CASR, PMA virtually abolished the response $(P<0.05$ by unpaired $t$-test).

\section{Discussion}

$\mathrm{ADH}$ in humans is a well-recognized consequence of activating mutations of the CASR, and a similar phenotype has been reported in the Nuf mouse, which is heterozygous for the CASR activating mutation L723Q (21). ADH is typically associated with increased $\mathrm{Ca}_{0}^{2+}$ sensitivity either from enhanced coupling between the receptor's extracellular $\mathrm{Ca}^{2+}$-binding domains and intracellular signaling domains, or from enhanced trafficking and surface expression (1). The findings reported here demonstrate that $\mathrm{ADH}$ can also arise when an inbuilt mechanism that uncouples the receptor from its intracellular signaling pathways is irreversibly disabled.

It has been shown previously that PTH secretion is increased by PKC activation in parathyroid cells exposed to moderate or high $\mathrm{Ca}_{\mathrm{o}}^{2+}$ concentrations that would otherwise suppress PTH secretion (22-27). Cloning of the CASR revealed PKC consensus sequences in its intracellular domain, and it was proposed that phosphorylation of one or more of these sites might uncouple the CASR from its downstream signaling pathway, thereby disinhibiting PTH secretion (28).

Of the five predicted PKC consensus sites in the human CASR C-terminus, T888 is functionally the most important in terms of phosphatidylinositol phospholipase C-dependent signaling in HEK-293 cells (13). Bai et al. (13) demonstrated this using site-directed mutagenesis of the five sites, finding that mutation of T888 substantially altered receptor sensitivity and responsiveness to PMA. In contrast, mutation of PKC sites T646 and S794 in the intracellular loops was without effect, and mutation of the intracellular domain residues S895 or S915 had only a small effect on receptor sensitivity and responsiveness to PMA (9). Specifically, mutation of $C A S R^{\mathrm{T} 888}$ to certain nonphosphorylatable residues (e.g. alanine and valine) increased apparent $\mathrm{Ca}_{0}^{2+}$ sensitivity of the CASR, whereas phosphomimetic mutations (e.g. aspartate and glutamate) attenuated $\mathrm{Ca}^{2+}$ sensitivity $(13,14)$. Rather than altering $\mathrm{Ca}_{0}^{2+}$ sensitivity per se as an extracellular mutation might, mutation of $C A S R^{T 888}$ modulates receptor-induced signaling, preventing CASR-mediated $\mathrm{Ca}_{\mathrm{i}}^{2+}$ mobilization when phosphorylated (as mimicked by $\mathrm{CASR}^{\mathrm{T} 888 \mathrm{D}}$ ) but permitting sustained CASR-mediated $\mathrm{Ca}_{\mathrm{i}}^{2+}$ mobilization when phosphorylation is prevented as in the case of CASR $^{\text {T888A }}$ in vitro $(12-15)$ or $\mathrm{CASR}^{\mathrm{T} 888 \mathrm{M}}$ in vivo as reported in this study.

As previous studies on the significance of T 888 for the control of CASR signaling were conducted using heterologous CASR expression in HEK-293 cells, it has been uncertain whether the $\mathrm{CASR}^{\mathrm{T} 888}$ residue exerts a critical function in vivo. Herein, we describe the clinical consequence of $\mathrm{CASR}^{\mathrm{T} 888}$ mutation in humans. As predicted by the in vitro studies, we found that $C A S R^{\mathrm{T}} 888 \mathrm{M}$
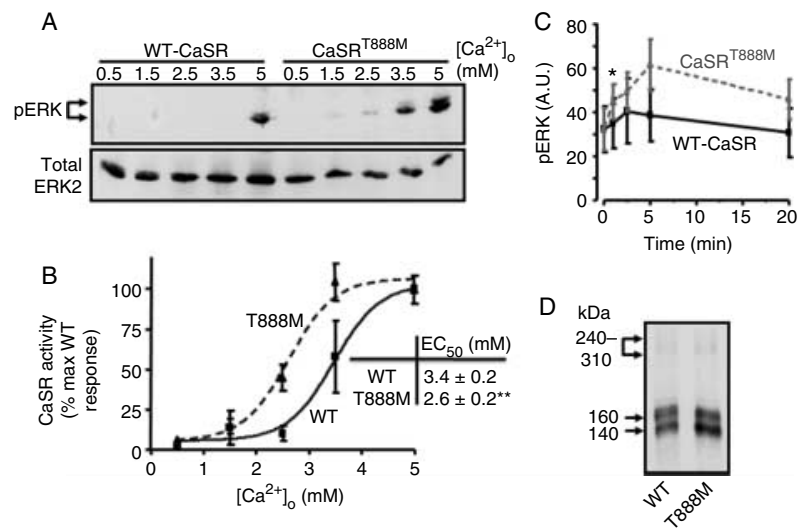

Figure 4 Effect of $C A S R^{\text {T888M }}$ mutation on extracellular $\mathrm{Ca}^{2+}$. induced ERK activation. (A) Representative western blots showing ERK-1/2 phosphorylation and total ERK-2 immunoreactivity in HEK293 cells transfected transiently with either wt-CASR or CASR ${ }^{\text {T888M }}$ following treatment for $10 \mathrm{~min}$ with different concentrations of $\mathrm{Ca}_{0}^{2+}$ up to $5 \mathrm{mM}$. (B) Quantification of the changes in ERK phosphorylation expressed as a percent of the maximal response in WT-CASR. $n=6$ from two independent transfections. ${ }^{\star \star} P<0.01$ WT-CASR versus CASR ${ }^{\text {T888M }}$ log $\mathrm{EC}_{50}$ values by paired $t$-test. (C) Similarly transfected cells were then stimulated with $4 \mathrm{mM} \mathrm{Ca}_{0}^{2+}$ for various time points up to $20 \mathrm{~min}$, and ERK phosphorylation was quantified as before. Results are displayed here graphically (arbitrary densitometry units). CaSR ${ }^{\text {T888M }}$ elicited greater ERK phosphorylation after $1 \mathrm{~min}\left({ }^{*} P<0.05\right.$ paired $t$-test) with no differences observed at any other time point. Data comprise five replicates from two separate transfections: wt-CaSR (black solid line) and CaSR ${ }^{\text {T888M }}$ (gray dashed line). (D) CASR immunoblot showing equivalent wt-CASR and CASR ${ }^{\top 888 \mathrm{M}}$ immunoreactivity in the samples as before. 
is a gain-of-function mutation in vivo, resulting in $\mathrm{ADH}$ featuring inappropriately suppressed serum PTH levels, hypercalciuria, and hypocalcemia. To our knowledge, this is the first clinical case report of a mutation disrupting T888 phosphorylation. It confirms the importance of T888 in CASR function and also supports the current model for its role in CASR signaling.

Live-cell imaging reveals that stimulation of the wt-CASR elicits $\mathrm{Ca}_{\mathrm{i}}^{2+}$ oscillations (29-32) in a PKCsensitive manner, with $\mathrm{PKC}$ activation reducing the frequency of $\mathrm{Ca}_{\mathrm{i}}^{2+}$ oscillations $(30,31)$. This suggests that CASR-mediated $\mathrm{Ca}_{\mathrm{i}}^{2+}$ oscillations result from negative feedback provided by PKC-mediated phosphorylation at T888, producing dynamic phosphorylation and dephosphorylation of CASR ${ }^{\mathrm{T} 888}$ (31). In addition, we show here for the first time that downstream ERK phosphorylation is affected similar to $\mathrm{Ca}_{i}^{2+}$ mobilization by $\mathrm{CASR}^{\mathrm{T} 888}$ mutation, with $\mathrm{CASR}^{\mathrm{T} 888 \mathrm{M}}$ exhibiting greater $\mathrm{Ca}_{\mathrm{o}}^{2+}$ sensitivity (Fig. 4) but without increasing cell surface expression of a FLAG-tagged receptor.

Recently, the use of a phospho-specific antibody against an epitope that included the phospho form of CASR $^{\text {T888 }}$ demonstrated PKC-mediated phosphorylation of the mature CASR in response to receptor activation, leading to feedback phosphorylation of $\mathrm{CASR}^{\mathrm{T} 888}$ (12). At lower levels of stimulation (i.e. $2 \mathrm{mM} \mathrm{Ca}_{\mathrm{o}}^{2+}$ ), $\mathrm{CASR}^{\mathrm{T} 888 \mathrm{M}}$ produced low frequency $\mathrm{Ca}_{\mathrm{i}}^{2+}$ oscillations, whereas the relatively high concentration of $3 \mathrm{mM} \mathrm{Ca}_{\mathrm{o}}^{2+}$ elicited mostly sustained responses (Figs 1 and 2) similar to that reported previously for CASR ${ }^{\mathrm{T} 888 \mathrm{~A}}$ (8). We have also recently shown that the pattern of CASR-elicited $\mathrm{Ca}_{\mathrm{i}}^{2+}$ mobilization is dependent on receptor-stimulated dephosphorylation of CASR ${ }^{\mathrm{T} 888}$, as it permits either the next $\mathrm{Ca}_{\mathrm{i}}^{2+}$ oscillation or even a sustained response (15). In the light of these previous in vitro data, the current clinical study indicates that loss of the CASR ${ }^{\mathrm{T} 888}$ phosphorylation site via a T to M mutation results in gain-of-function at the level of the parathyroid gland and in turn, a significant disturbance of whole body calcium homeostasis. Furthermore, it is consistent with the presence of some degree of basal phosphorylation of the wt-CASR by PKC in vivo, which tonically suppresses the activity of the receptor under normocalcemic conditions. Loss of the capacity of PKC to phosphorylate $\mathrm{CASR}^{\mathrm{T} 888 \mathrm{M}}$ should remove this inhibitory action, thereby increasing the activity of the mutant CASR and producing the biochemical phenotype of $\mathrm{ADH}$.

Interestingly, $1,25(\mathrm{OH})_{2} \mathrm{D}$ was initially elevated in the index case, but was normal in his father. The conversion of $250 \mathrm{OHD}$ to its active metabolite $1,25(\mathrm{OH})_{2} \mathrm{D}$ is mediated by $1 \alpha$-hydroxylase, a crucial regulatory enzyme of predominantly renal origin. Hypocalcemia stimulates renal $1 \alpha$-hydroxylase activity independently of PTH and hypophosphatemia (33), and although the CASR is expressed in renal proximal tubule cells (34), it is not yet clear whether it mediates the effect of low serum $\mathrm{Ca}_{0}^{2+}$ concentration on $1 \alpha$-hydroxylase.
The current findings point either to the possibility of a CASR-independent mechanism or to a CASR signaling pathway whose sensitivity to serum $\mathrm{Ca}_{\mathrm{o}}^{2+}$ concentration is not enhanced by the T888M mutation.

In conclusion, we have described a family with $\mathrm{ADH}$ due to a novel CASR mutation, T888M. This case provides the first reported genotype-phenotype correlation of a mutation at this site, confirms previous in vitro findings that identified T888 as an important phosphorylation site in the CASR, and supports the current model for its role in CASR-mediated intracellular signaling.

\section{Declaration of interest}

The authors declare that there is no conflict of interest that could be perceived as prejudicing the impartiality of the research reported.

\section{Funding}

The in vitro portion of this work was supported by Kidney Research UK (IN4/2008) and by Biotechnology and Biological Sciences Research Council, UK quota studentship.

\section{Acknowledgements}

The authors would like to thank Dr Adrian Kark and A/Prof. Michael d'Emden (Royal Brisbane and Women's Hospital) for their involvement in the routine management of the case, Mr Matthew Crompton, Dr John Cardinal, and Dr Jacobus Ungerer (Pathology Queensland) for their assistance with the DNA sequencing, Ms Rebecca Atkinson-Dell (University of Manchester) and Ms Karolina Windloch (University of Sydney) for their assistance in generating the CASR mutants, and Dr Austin Elliott (University of Manchester) for his assistance with the intracellular calcium imaging.

\section{References}

1 Egbuna OI \& Brown EM. Hypercalcaemic and hypocalcaemic conditions due to calcium-sensing receptor mutations. Best Practice $\mathcal{E}$ Research. Clinical Rheumatology 200822 129-148. (doi:10.1016/j.berh.2007.11.006)

2 Gunn IR \& Gaffney D. Clinical and laboratory features of calciumsensing receptor disorders: a systematic review. Annals of Clinical Biochemistry 200441 441-458. (doi:10.1258/0004563 042466802)

3 Thakker RV. Diseases associated with the extracellular calciumsensing receptor. Cell Calcium 200435 275-282. (doi:10.1016/j. ceca.2003.10.010)

4 Hendy GN, Guarnieri V \& Canaff L. Chapter 3 calcium-sensing receptor and associated diseases. Progress in Molecular Biology and Translational Science 2009 89C 31-95. (doi:10.1016/S18771173(09)89003-0)

$5 \mathrm{Hu} \mathrm{J} \&$ Spiegel AM. Structure and function of the human calciumsensing receptor: insights from natural and engineered mutations and allosteric modulators. Journal of Cellular and Molecular Medicine 200711 908-922. (doi:10.1111/j.1582-4934.2007.00096.x)

6 Lienhardt A, Bai M, Lagarde J, Rigaud M, Zhang Z, Jiang Y, Kottler M \& Brown E. Activating mutations of the calcium-sensing receptor: management of hypocalcemia. Journal of Clinical Endocrinology and Metabolism 200186 5313-5323. (doi:10. 1210/jc.86.11.5313)

7 Pearce SH, Williamson C, Kifor O, Bai M, Coulthard MG, Davies M, Lewis-Barned N, McCredie D, Powell H, Kendall-Taylor P, Brown EM \& Thakker RV. A familial syndrome of hypocalcemia 
with hypercalciuria due to mutations in the calcium-sensing receptor. New England Journal of Medicine 1996335 1115-1122. (doi:10.1056/NEJM199610103351505)

8 Mittelman SD, Hendy GN, Fefferman RA, Canaff L, Mosesova I, Cole DE, Burkett L \& Geffner ME. A hypocalcemic child with a novel activating mutation of the calcium-sensing receptor gene: successful treatment with recombinant human parathyroid hormone. Journal of Clinical Endocrinology and Metabolism 2006 91 2474-2479. (doi:10.1210/jc.2005-2605)

9 Canaff L \& Hendy GN. Human calcium-sensing receptor gene. Vitamin D response elements in promoters P1 and P2 confer transcriptional responsiveness to 1,25-dihydroxyvitamin D. Journal of Biological Chemistry $2002 \quad 277$ 30337-30350. (doi:10.1074/jbc.M201804200)

10 Ward DT. Calcium receptor-mediated intracellular signalling. Cell Calcium 200435 217-228. (doi:10.1016/j.ceca.2003.10.017)

11 Brennan SC \& Conigrave AD. Regulation of cellular signal transduction pathways by the extracellular calcium-sensing receptor. Current Pharmaceutical Biotechnology 200910 270-281. (doi:10. 2174/138920109787847484)

12 Davies SL, Ozawa A, McCormick WD, Dvorak MM \& Ward DT. Protein kinase C-mediated phosphorylation of the calcium-sensing receptor is stimulated by receptor activation and attenuated by calyculin-sensitive phosphatase activity. Journal of Biological Chemistry $2007 \quad 282$ 15048-15056. (doi:10.1074/jbc. M607469200)

13 Bai M, Trivedi S, Lane CR, Yang Y, Quinn SJ \& Brown EM. Protein kinase $\mathrm{C}$ phosphorylation of threonine at position 888 in $\mathrm{Ca}_{0}^{2+}$. sensing receptor (CaR) inhibits coupling to $\mathrm{Ca}^{2+}$ store release. Journal of Biological Chemistry 1998273 21267-21275. (doi:10. $1074 /$ jbc.273.33.21267)

14 Jiang YF, Zhang Z, Kifor O, Lane CR, Ouinn SJ \& Bai M. Protein kinase $\mathrm{C}$ (PKC) phosphorylation of the $\mathrm{Ca}_{0}^{2+}$-sensing receptor $(\mathrm{CaR})$ modulates functional interaction of $\mathrm{G}$ proteins with the CaR cytoplasmic tail. Journal of Biological Chemistry 2002277 50543-50549. (doi:10.1074/jbc.M205798200)

15 McCormick WD, Atkinson-Dell R, Campion KL, Mun HC, Conigrave AD \& Ward DT. Increased receptor stimulation elicits differential calcium-sensing receptor (T888) dephosphorylation. Journal of Biological Chemistry 2010285 14170-14177. (doi:10. 1074/jbc.M109.071084)

16 Knox S, Harris J, Calton L \& Wallace AM. A simple automated solid-phase extraction procedure for measurement of 25-hydroxyvitamin $\mathrm{D}_{3}$ and $\mathrm{D}_{2}$ by liquid chromatography-tandem mass spectrometry. Annals of Clinical Biochemistry 200946 226-230. (doi:10.1258/acb.2009.008206)

17 Tan Y, Cardinal J, Franks A, Mun H, Lewis N, Harris L, Prins J \& Conigrave A. Autosomal dominant hypocalcemia: a novel activating mutation $(\mathrm{E} 604 \mathrm{~K})$ in the cysteine-rich domain of the calcium-sensing receptor. Journal of Clinical Endocrinology and Metabolism 200388 605-610. (doi:10.1210/jc.2002-020081)

18 Ward DT, Brown EM \& Harris HW. Disulfide bonds in the extracellular calcium-polyvalent cation-sensing receptor correlate with dimer formation and its response to divalent cations in vitro. Journal of Biological Chemistry 1998273 14476-14483. (doi:10. $1074 /$ jbc.273.23.14476)

19 Ward DT, McLarnon SJ \& Riccardi D. Aminoglycosides increase intracellular calcium levels and ERK activity in proximal tubular OK cells expressing the extracellular calcium-sensing receptor Journal of the American Society of Nephrology 200213 1481-1489. (doi:10.1097/01.ASN.0000015623.73739.B8)

20 Bai M, Trivedi S \& Brown EM. Dimerization of the extracellular calcium-sensing receptor (CaR) on the cell surface of CaRtransfected HEK293 cells. Journal of Biological Chemistry 1998 273 23605-23610. (doi:10.1074/jbc.273.36.23605)
21 Hough TA, Bogani D, Cheeseman MT, Favor J, Nesbit MA, Thakker RV \& Lyon MF. Activating calcium-sensing receptor mutation in the mouse is associated with cataracts and ectopic calcification. PNAS 2004101 13566-13571. (doi:10.1073/ pnas.0405516101)

22 Membreno L, Chen TH, Woodley S, Gagucas R \& Shoback D. The effects of protein kinase-C agonists on parathyroid hormone release and intracellular free $\mathrm{Ca}^{2+}$ in bovine parathyroid cells. Endocrinology 1989124 789-797. (doi:10. 1210/endo-124-2-789)

23 Nemeth EF, Wallace J \& Scarpa A. Stimulus-secretion coupling in bovine parathyroid cells. Dissociation between secretion and net changes in cytosolic $\mathrm{Ca}^{2+}$. Journal of Biological Chemistry 1986 $2612668-2674$.

24 Kobayashi N, Russell J, Lettieri D \& Sherwood LM. Regulation of protein kinase $\mathrm{C}$ by extracellular calcium in bovine parathyroid cells. PNAS $1988 \mathbf{8 5}$ 4857-4860. (doi:10.1073/pnas.85.13. 4857)

25 Morrissey JJ. Effect of phorbol myristate acetate on secretion of parathyroid hormone. American Journal of Physiology. Endocrinology and Metabolism 1988254 E63-E70.

26 Nygren P, Gylfe E, Larsson R, Johansson H, Juhlin C, Klareskoq L, Akerstrom $\mathrm{G} \&$ Rastad J. Modulation of the $\mathrm{Ca}^{2+}$-sensing function of parathyroid cells in vitro and in hyperparathyroidism. Biochimica et Biophysica Acta 1988968 253-260. (doi:10.1016/01674889(88)90014-6)

27 Racke FK \& Nemeth EF. Protein kinase C modulates hormone secretion regulated by extracellular polycations in bovine parathyroid cells. Journal of Physiology $1993 \mathbf{4 6 8} 163-176$.

28 Brown EM, Gamba G, Riccardi D, Lombardi M, Butters R, Kifor O, Sun A, Hediger MA, Lytton J \& Hebert SC. Cloning and characterization of an extracellular $\mathrm{Ca}(2+)$-sensing receptor from bovine parathyroid. Nature 1993366 575-580. (doi:10. 1038/366575a0)

29 Breitwieser GE. Calcium sensing receptors and calcium oscillations: calcium as a first messenger. Current Topics in Developmental Biology 200673 85-114. (doi:10.1016/S0070-2153(05) 73003-9)

30 Young SH \& Rozengurt E. Amino acids and $\mathrm{Ca}^{2+}$ stimulate different patterns of $\mathrm{Ca}^{2+}$ oscillations through the $\mathrm{Ca}^{2+}$-sensing receptor. American Journal of Physiology. Cell Physiology 2002282 C1414-C1422. (doi:10.1152/ajpcell.00432.2001)

31 Young SH, Wu SV \& Rozengurt E. $\mathrm{Ca}^{2+}$-stimulated $\mathrm{Ca}^{2+}$ oscillations produced by the $\mathrm{Ca}^{2+}$-sensing receptor require negative feedback by protein kinase C. Journal of Biological Chemistry 2002277 46871-46876. (doi:10.1074/jbc.M207083200)

32 Breitwieser GE \& Gama L. Calcium-sensing receptor activation induces intracellular calcium oscillations. American Journal of Physiology. Cell Physiology 2001280 C1412-C1421.

33 Bland R, Walker EA, Hughes SV, Stewart PM \& Hewison M. Constitutive expression of 25-hydroxyvitamin D3-1 $\alpha$-hydroxylase in a transformed human proximal tubule cell line: evidence for direct regulation of vitamin $\mathrm{D}$ metabolism by calcium. Endocrinology 1999140 2027-2034. (doi:10.1210/en.140.5. 2027)

34 Riccardi D, Hall AE, Chattopadhyay N, Xu JZ, Brown EM \& Hebert SC. Localization of the extracellular $\mathrm{Ca}^{2+}$ /polyvalent cation-sensing protein in rat kidney. American Journal of Physiology 1998274 F611-F622.

Received 14 November 2010

Accepted 15 November 2010 